\title{
The effect of a low-calorie diet with and without fenfluramine on the glucose tolerance and insulin secretion of obese maturity-onset diabetics
}

\author{
J. RANALD W. DYKeS \\ M.B., Ch.B., B.Sc. \\ Department of Chemical Pathology, The University of Leeds
}

\begin{abstract}
Summary
Glucose tolerance and insulin secretion have been measured in twenty-three obese maturity-onset diabetics (twelve high-insulin secretors and eleven lowor normal-insulin secretors) on first presentation and after 10 weeks on a low-calorie diet. There was a significant improvement in glucose tolerance alone, when the results were compared with those from diabetics not on any form of treatment.

Thereafter nine of these subjects (five high-insulin secretors and four low- or normal-insulin secretors) continued on the dietary therapy alone, and eleven of the remaining fourteen subjects (six high-insulin secretors and five low- or normal-insulin secretors) continued on the low-calorie diet with the addition of fenfluramine, and their glucose tolerance and insulin secretion were measured again after a further 10 weeks. The remaining three subjects were no longer studied. The nine subjects continuing on the diet alone showed maintenance of the improvement in glucose tolerance achieved during the first 10 -week period with no significant change in insulin secretion. The eleven subjects placed on fenfluramine in addition to the diet also showed maintenance of the improvement in glucose tolerance achieved during the first 10-week period with a significant decrease in insulin secretion in the six high-insulin secreting subjects and no significant change in insulin secretion in the five lowor normal-secretors.
\end{abstract}

\section{Introduction}

For many years it has been known that the glucose tolerance of some obese diabetics was considerably improved after a period on a low carbohydrate diet (Himsworth, 1949). Karam et al. (1965) demonstrated an improvement in glucose tolerance and reduction of insulin secretion to normal in an 18-yearold obese diabetic female subject who reduced from $20 \%$ overweight to $5 \%$ underweight on a diet of 800 calories/day for 9 weeks. Rudnick \& Taylor (1965) showed an improvement in glucose tolerance and increase in insulin secretion in seven mild diabetic subjects with widely differing degrees of obesity after 2 months' treatment with a lowcarbohydrate diet. Hales, Stein \& Stowers (1966) studied the glucose tolerance of a group of very obese diabetic subjects before and after a period on a very low carbohydrate diet, and showed that in those patients with a deterioration of glucose tolerance after the diet, plasma insulin concentrations increased, whereas patients whose glucose tolerance was improved on the diet showed decreased insulin concentrations. McKiddie \& Buchanan (1969) found a significant reduction in the average blood sugar values and a significant increase in the average insulin secretory response in twenty-two maturity onset low- or normal-insulin secreting diabetics controlled on dietary therapy alone for periods of time varying from 3-18 months. Because of the conflicting nature of these various results, in this paper the effect of a low-carbohydrate diet for a period of 10 weeks on the gluco:e tolerance and insulin secretion of twenty-three newly diagnosed obese maturity-onset diabetics is described; an attempt is made to categorize them according to initial insulin secretion and initial weight, to standardize the conditions of the method of study, and to compare the results statistically with those from controls studied in identical manner. Further study of the glucose tolerance and insulin secretion has been made after addition of fenfluramine to the dietary regimen in eleven of the subjects.

Fenfluramine is a non-addictive amphetamine derivative with appetite-depressing activity (Foxwell, Funderburk \& Ward, 1969), and is used along with dietary control in the treatment of obesity since it produces greater loss in weight than other anorexigenic amphetamines (Craddock, 1969). An indication that fenfluramine might have a further action in addition to its appetite-depressing property arose when von Herold, Kemper \& Opitz (1965) recorded that the drug brought about a reduction in the blood glucose concentration in rats. Subsequently, using the forearm preparation of Butterfield \& Holling (1959), several workers have shown that intraarterial infusion of the drug increases the uptake of glucose and oxygen by muscle independently of alteration in blood flow (Whichelow et al., 1971; Turtle, Burgess \& Bauckham, 1971). Because of this effect on carbohydrate metabolism the effect of fenfluramine was studied as an aid to dietary treatment in maturity-onset obese diabetics. 
Kipnis (1968) suggested that the basic metabolic abnormality in diabetes mellitus is a delayed insulin secretory response to glucose. The effect of diet with and without fenfluramine on this was also studied.

\section{Patients and methods \\ Patients}

Twenty-three obese maturity-onset diabetics on their first presentation at the Outpatient Clinic were studied; they were between 40 and 65 years of age, did not require insulin therapy, and were able to co-operate intelligently in a study of this type; they were more than $10 \%$ overweight at the commencement of the study as calculated from the height and ideal weight tables issued by the American Society of Actuaries (1959).

After a baseline oral glucose-tolerance and insulinsecretion test, each patient was started on a lowcarbohydrate diet chosen by the clinician individually for each subject and continued on this treatment under the supervision of the dietician and the Diabetic Clinic for 10 weeks, when the second oral glucose-tolerance and insulin-secretion test was carried out. Thereafter eleven of these obese subjects were randomly selected and placed on fenfluramine $40 \mathrm{mg}$ twice daily in addition to the diet, whereas nine of the remaining twelve subjects continued on the dietary therapy alone. The remaining three subjects were no longer studied. A third glucosetolerance and insulin-secretion test was carried out on these twenty subjects after a further 10 weeks.

Twelve maturity-onset diabetics who did not adhere to their diet and who were not on any other form of therapy had baseline oral glucose-tolerance and insulin-secretion tests followed by repeat tests after 10 weeks. These acted as controls against whom the changes in the subjects who did adhere to treatment, could be assessed.

A normal range of insulin secretion was obtained from twenty-one normal individuals (eight males and thirteen females) aged from 36 to 63 years. Each had a normal oral glucose-tolerance test, was within $5 \%$ of his or her ideal body weight, and had none of the associations of the prediabetic state (large babies, family history, etc.). In order to establish the reproducibility of measurement of the parameters being studied, oral glucose-tolerance and insulin-secretion tests were repeated on eleven of these normal subjects (six males and five females).

\section{Laboratory estimations}

For at least 4 days before the initial oral glucosetolerance and insulin-secretion test, each subject had eaten a diet containing at least $200 \mathrm{~g}$ carbohydrate/ day. All subjects, both diabetic and normal fasted for $13 \mathrm{hr}$ prior to each test. Fenfluramine was also withdrawn for 13-15 hr before each test which was carried out as follows: after the fasting venous blood specimen was taken, each subject ingested $50 \mathrm{~g}$ glucose in $400 \mathrm{ml}$ water within $3 \mathrm{~min}$. Venous blood specimens were taken at 15, 30, 60, 90, 120 and 150 min for glucose and insulin assay. Urine specimens were collected immediately before, and 1 and $2 \mathrm{hr}$ after the glucose ingestion and were tested semiquantitatively for total reducing substance by Clinitest tablets.

The specimens were assayed for glucose by the AutoAnalyzer glucose oxidase method of Morley, Dawson \& Marks (1968), the coefficient of variation being $4.6 \%$ at a blood glucose concentration of $106 \mathrm{mg} / 100 \mathrm{ml}$. Plasma immunoreactive insulin was measured in duplicate on each specimen by the method of Hales \& Randle (1963) using radioactive iodinated insulin and Oxoid membrane filters supplied by the Radiochemical Centre at Amersham. The pre-precipitated antibody and standard human insulin were supplied by Burroughs Wellcome. The standard deviation of the assay method was: (a) $\pm 2.92 \mu \mathrm{U} / \mathrm{ml}$ for 115 duplicate determinations of $0-49 \mu \mathrm{U} / \mathrm{ml}$, (b) $\pm 6 \cdot 51 \mu \mathrm{U} / \mathrm{ml}$ for 64 of $50-99 \mu \mathrm{U} / \mathrm{ml}$ and (c) $\pm 7 \cdot 25 \mu \mathrm{U} / \mathrm{ml}$ for 55 of $100-200 \mu \mathrm{U} / \mathrm{ml}$. If a plasma insulin concentration $>200 \mu \mathrm{U} / \mathrm{ml}$ was found, the sample was diluted to $<200 \mu \mathrm{U} / \mathrm{ml}$, and then re-assayed. Otherwise all specimens from one subject were determined in the same batch.

\section{Categorization of patients studied and statistical methods of comparison}

The area under the glucose-tolerance test curve from 0 to $2 \frac{1}{2} \mathrm{hr}$ was measured as an index of glucose tolerance (Burns et al., 1965); a decrease in the area represents an improvement in this parameter. Insulin secretion was represented by the area under the plasma insulin curve from 0 to $2 \frac{1}{2} \mathrm{hr}$ (Perley \& Kipnis, 1965). The range of insulin secretion obtained from the normal controls was $1200-5003 \mu \mathrm{U}-\mathrm{min} / \mathrm{ml}$ so that patients producing quantities of insulin less than $1200 \mu \mathrm{U}-\mathrm{min} / \mathrm{ml}$, between 1200 and 5003 $\mu \mathrm{U}-\mathrm{min} / \mathrm{ml}$ and greater than $5003 \mu \mathrm{U}-\mathrm{min} / \mathrm{ml}$ are referred to as low-, normal- and high-secretors respectively.

Of the eleven obese subjects placed on fenfluramine in addition to the diet for the second 10-week period, six were high-insulin secretors and five low- or normal-insulin secretors on first presentation. Of the nine subjects continuing on the diet alone for the second 10-week period five were high secretors and four low or normal secretors.

To obtain an assessment of the reproducibility of measurement of the glucose tolerance, the difference between the two indices from each of the eleven healthy normal individuals on whom the oral glucose-tolerance test was repeated, was expressed as a percentage of the mean of the two indices. Similarly for the patients, the difference between the 
glucose-tolerance indices of two consecutive tests was expressed as a percentage of the mean of the two indices. Likewise, percentages were calculated for the differences in consecutive insulin secretions. Knowing the reproducibility of measurement of the glucose tolerance and insulin secretion, the probability that the changes in these parameters were due to random variation in their estimation was calculated by statistically comparing the percentages from the patients with those from the normal subjects by the non-parametric Mann-Whitney U-test as described by Sokal \& Rohlf (1969).

Similar changes occurring in the percentages in glucose tolerance and insulin secretion were calculated for the diabetics not adhering to any form of treatment. The changes in the subjects adhering to diet could be compared with the latter as controls by the Mann-Whitney U-test.

The following controls were used to assess the significance of the changes in the patients on diet plus fenfluramine. They were compared: (i) with the reproducibility of the measurements on the eleven healthy normal subjects; (ii) with the changes in those patients who were not adhering to the diet and who were not on any other form of therapy; (iii) with the changes in the same category of diabetic continuing on diet alone for the same 10-week period; (iv) with the changes in the same subjects on diet alone during the first 10-week period.

The average time in minutes of occurrence of the peak of the insulin curve in the diabetics on first presentation was compared with that of the normal controls. A comparison was also made with the time of occurrence of the peak after the various forms of treatment.

The range of insulin secretion in the first $\frac{1}{2}$ and $1 \mathrm{hr}$ of the glucose-tolerance test was compared in the high-insulin secreting individuals with the normal- or low-insulin secreting individuals to see whether in the initial stages of the glucose-tolerance test there was a significant difference between the two groups in the amount of insulin secreted.

\section{Results}

Figures 1 and 2 show on a semi-logarithmic scale the glucose tolerance and insulin secretion of (a) twenty-one normal subjects, (b) eleven normal subjects on whom a repeat test was performed, (c) seventeen obese maturity-onset diabetics, baseline and after two successive 10-week periods on various types of therapy. The results are not shown from the six low- or normal-secretors on diet alone for the first 10-week period, four of whom were studied for the second period of 10 weeks continuing on diet alone. The results are shown from the one highinsulin secretor studied only for the first 10 -week period.

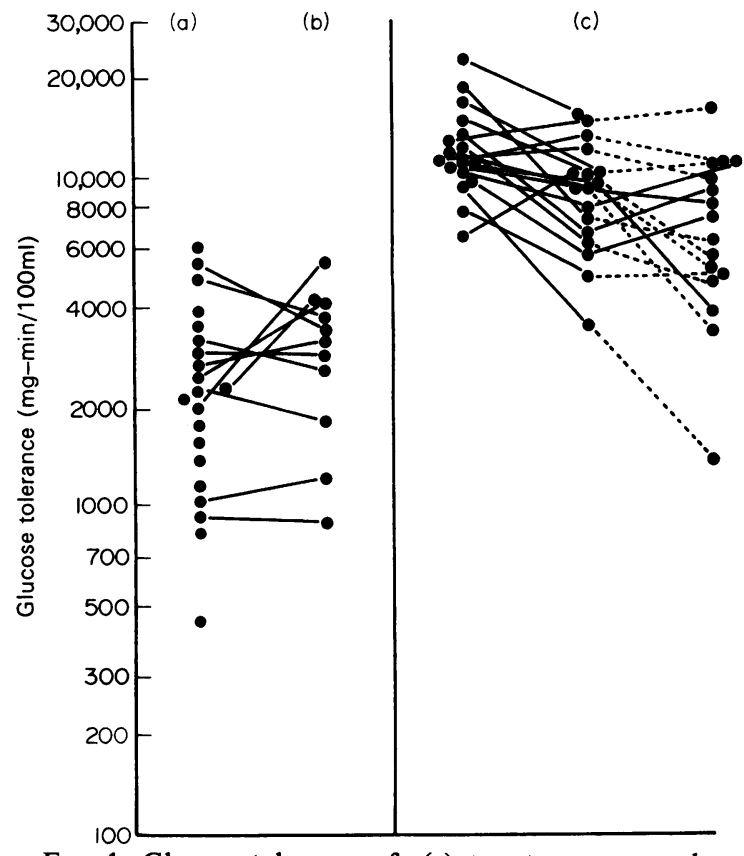

FIG. 1. Glucose tolerance of: (a) twenty-one normal subjects, (b) the eleven normal subjects on whom a repeat test was performed, (c) seventeen obese maturityonset diabetics, baseline and after therapy. diet alone; .... diet plus fenfluramine.

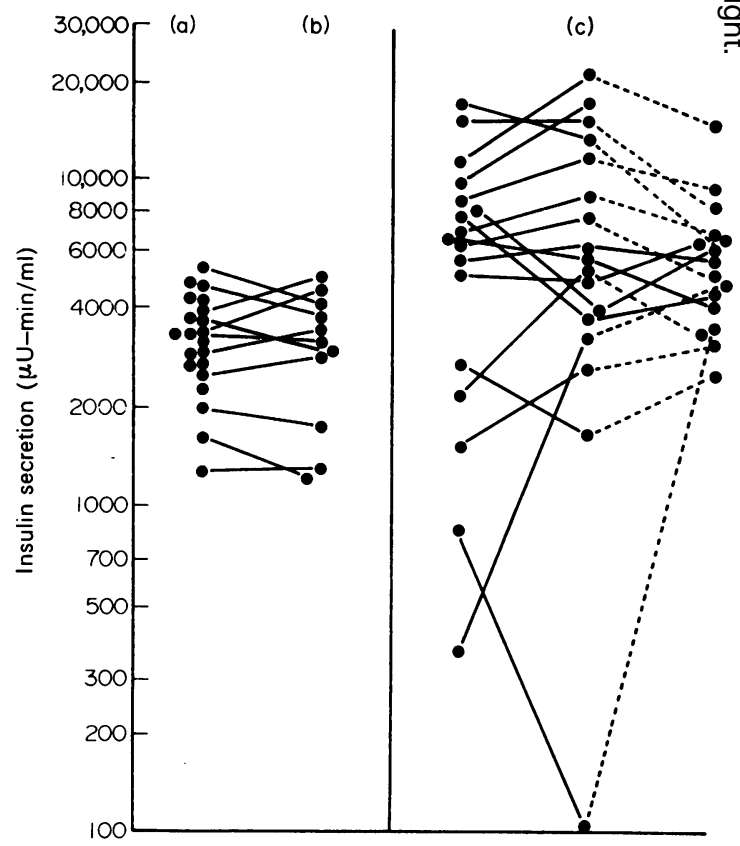

FIG. 2. Insulin secretion of: (a) twenty-one normal subjects, (b) the eleven normal subjects on whom a repeat test was performed and, (c) seventeen obese maturity-onset diabetics, baseline and after therapy. fluramine. 
Tables 1 and 2 demonstrate the statistical significance of the effect of dietary therapy alone and dietplus-fenfluramine respectively on the glucose tolerance and insulin secretion of obese maturity-onset diabetics, when the results are compared with the various controls.

Table 3 shows the average time in minutes of occurrence of the peak of the insulin curve in (a) diabetics after various forms of therapy, and (b) in normal controls and compares them with that in diabetics on first presentation, i.e. untreated.

Table 4 shows the range of insulin secretion during the first 30 and 60 min of the OGTT in diabetics categorized as 'high-insulin' secreting and 'low- or norma-insulin' secreting on first presentation.

Weight-loss occurred in all subjects who adhered to therapy. Glycosuria was present during all tests except those in the high-insulin secreting subjects after 10 weeks on diet-plus-fenfluramine. By the criteria of McKiddie \& Buchanan (1969), control of the diabetes was achieved in all subjects studied who adhered to therapy.

\section{Discussion}

Untreated diabetics have a variable insulin response to oral glucose, a few producing an excess quantity and most a normal or subnormal amount, as previously shown by McKiddie \& Buchanan (1969). Eleven out of 178 subjects in their series were 'high-insulin-secretors', as compared with twelve out of seventy-seven reported in the present paper. This excess insulin secretion found in a few maturityonset diabetics is associated with obesity (Karam et al., 1965; Perley \& Kipnis, 1966; McKiddie \& Buchanan, 1969) and occurs also in obese nondiabetics (Yalow et al., 1965; Dykes, 1973). The treatment of twenty-three obese maturity-onset diabetics (twelve 'high-insulin-secreting' and eleven 'low- or normal-insulin-secreting') for a period of 10 weeks with low carbohydrate diet produced a significant improvement in glucose tolerance in both categories $(0.02>P>0.01)$ (Table 1$)$ but no significant effect on the insulin secretion. In the series of Rudnick \& Taylor (1965) the subjects were of widely differing initial degrees of obesity, and those of McKiddie \& Buchanan (1969) were tested after widely differing periods of time on dietary therapy, viz. from 3 to 18 months. Nine of the original twenty-three subjects in this paper (five 'highsecretors' and four 'low- or normal-secretors') were retested after a further 10-week period on dietary therapy alone and there was st:ll a significant improvement in glucose tolerance $(0.05>P>0.02)$ in the 'high-secretors,' but only a marginally significant

TABLE 1. Statistical significance of the effect of dietary therapy alone on the glucose tolerance and insulin secretion of two categories of obese maturity-onset diabetics when the results are compared with various controls

(all subjects dieted up to each test)

\begin{tabular}{|c|c|c|c|c|}
\hline & \multicolumn{2}{|c|}{$\begin{array}{l}\text { Obese 'high-insulin' secretors on } \\
\text { diet alone for first } 10 \text { weeks }\end{array}$} & \multicolumn{2}{|c|}{$\begin{array}{l}\text { Obese 'low- or normal-secretors' or } \\
\text { diet alone for first } 10 \text { weeks }\end{array}$} \\
\hline & \multicolumn{2}{|c|}{ Change in: } & \multicolumn{2}{|c|}{ Change in: } \\
\hline & $\begin{array}{l}\text { Glucose } \\
\text { tolerance }\end{array}$ & $\begin{array}{l}\text { Insulin } \\
\text { secretion }\end{array}$ & $\begin{array}{l}\text { Glucose } \\
\text { tolerance }\end{array}$ & $\begin{array}{l}\text { Insulin } \\
\text { secretion }\end{array}$ \\
\hline $\begin{array}{l}\text { Reproducibility of glucose tolerance in normal } \\
\text { subjects }\end{array}$ & $\begin{array}{l}\text { Significant } \\
\text { improvement } \\
P=0.05\end{array}$ & - & $\begin{array}{l}\text { Significant } \\
\text { improvement } \\
P=0.05\end{array}$ & - \\
\hline $\begin{array}{l}\text { Reproducibility of insulin secretion in normal } \\
\text { subjects }\end{array}$ & - & NS* & - & NS \\
\hline $\begin{array}{l}\text { Change in glucose tolerance of diabetics not ad- } \\
\text { hering for a } 10 \text {-week period to any treatment }\end{array}$ & $\begin{array}{l}\text { Significant } \\
\text { improvement } \\
0.02>P>0.01\end{array}$ & - & $\begin{array}{l}\text { Significant } \\
\text { improvement } \\
0.02>P>0.01\end{array}$ & - \\
\hline $\begin{array}{l}\text { Change in insulin secretion of diabetics not } \\
\text { adhering for a } 10 \text {-week period to any treat- } \\
\text { ment }\end{array}$ & - & NS & - & NS \\
\hline $\begin{array}{l}\text { Change in glucose tolerance of the same obese } \\
\text { 'high-secretors' on diet alone for second } 10 \\
\text { weeks }\end{array}$ & NS & - & - & - \\
\hline $\begin{array}{l}\text { Change in insulin secretion of the same obese } \\
\text { 'high-secretors' on diet alone for second } 10 \\
\text { weeks }\end{array}$ & - & NS & - & - \\
\hline $\begin{array}{l}\text { Change in glucose tolerance of the same obese } \\
\text { 'low- or normal-secretors' on diet alone for } \\
\text { second } 10 \text { weeks }\end{array}$ & - & - & NS & - \\
\hline $\begin{array}{l}\text { Change in insulin secretion of the same obese } \\
\text { 'low- or normal-secretors' on diet alone for } \\
\text { second } 10 \text { weeks }\end{array}$ & - & - & - & NS \\
\hline
\end{tabular}

* NS, not significant. 
TABLE 2. Statistical significance of diet-plus-fenfluramine on the glucose tolerance and insulin secretion of obese maturityonset diabetics when the results are compared with various controls

\begin{tabular}{|c|c|c|c|c|c|}
\hline & \multirow{2}{*}{\multicolumn{2}{|c|}{$\begin{array}{l}\text { Obese 'high-insulin' secretors on } \\
\text { diet-plus-fenfluramine for second } \\
10 \text { weeks }\end{array}$}} & \multicolumn{3}{|c|}{$\begin{array}{l}\text { Obese 'low-or normal-secretors' on } \\
\text { diet-plus-fenfluramine for second } \\
10 \text { weeks }\end{array}$} \\
\hline & & & \multicolumn{3}{|c|}{ Change in: } \\
\hline & $\begin{array}{l}\text { Glucose } \\
\text { tolerance }\end{array}$ & $\begin{array}{l}\text { Insulin } \\
\text { secretion }\end{array}$ & $\begin{array}{l}\text { Glucose } \\
\text { tolerance }\end{array}$ & $\begin{array}{l}\text { Insulin } \\
\text { secretion }\end{array}$ & \\
\hline $\begin{array}{l}\text { Reproducibility of glucose tolerance in normal } \\
\text { subjects }\end{array}$ & $\begin{array}{l}\text { Significant } \\
\text { improvement } \\
P=0.05\end{array}$ & - & NS* & - & \\
\hline $\begin{array}{l}\text { Reproducibility of insulin secretion in normal } \\
\text { subjects }\end{array}$ & - & $\begin{array}{l}\text { Significant } \\
\text { decrease } \\
P=0.002\end{array}$ & - & NS & \\
\hline $\begin{array}{l}\text { Change in glucose tolerance of diabetics not } \\
\text { adhering to any form of treatment for a } \\
10 \text {-week period }\end{array}$ & $\begin{array}{l}\text { Significant } \\
\text { improvement } \\
P=0.01\end{array}$ & - & NS & - & \\
\hline $\begin{array}{l}\text { Change in insulin secretion of diabetics not } \\
\text { adhering to any form of treatment for a } \\
10 \text {-week period }\end{array}$ & - & $\begin{array}{l}\text { Significant } \\
\text { decrease } \\
0.01>P>0.002\end{array}$ & -- & NS & \\
\hline $\begin{array}{l}\text { Change in glucose tolerance of obese 'high- } \\
\text { secretors' on diet alone for same 10-week } \\
\text { period }\end{array}$ & NS & - & - & - & \\
\hline $\begin{array}{l}\text { Change in insulin secretion of obese 'high- } \\
\text { secretors' on diet alone for same 10-week } \\
\text { period }\end{array}$ & - & $\begin{array}{l}\text { Significant } \\
\text { decrease } \\
P=0.01\end{array}$ & - & 一 & \\
\hline $\begin{array}{l}\text { Change in glucose tolerance of obese 'low-or } \\
\text { normal-secretors' on diet alone for same } \\
10 \text {-week period }\end{array}$ & - & - & NS & - & 응 \\
\hline $\begin{array}{l}\text { Change in insulin secretion of obese 'low-or } \\
\text { normal-secretors' on diet alone for same } \\
10 \text {-week period }\end{array}$ & - & - & - & NS & 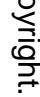 \\
\hline $\begin{array}{l}\text { Change in glucose tolerance of the same obese } \\
\text { 'high-secretors' on diet alone for first } 10 \\
\text { weeks }\end{array}$ & NS & -- & - & - & \\
\hline $\begin{array}{l}\text { Change in insulin secretion of the same obese } \\
\text { 'high-secretors' on diet alone for first } 10 \\
\text { weeks }\end{array}$ & - & $\begin{array}{l}\text { Marginally } \\
\text { significant } \\
\text { decrease } \\
P=0 \cdot 10\end{array}$ & - & - & \\
\hline $\begin{array}{l}\text { Change in glucose tolerance of the same obese } \\
\text { 'low- or normal-secretors' on diet alone for } \\
\text { first } 10 \text { weeks }\end{array}$ & - & - & NS & - & \\
\hline $\begin{array}{l}\text { Change in insulin secretion of the same obese } \\
\text { 'low- or normal-secretors' on diet alone for } \\
\text { first } 10 \text { weeks }\end{array}$ & - & - & - & NS & \\
\hline
\end{tabular}

* NS, not significant.

improvement in glucose tolerance $(0 \cdot 10>P>0.05)$ in the 'low- or normal-secretors'. When the changes in glucose tolerance and insulin secretion during the second 10-week period on diet were compared with the changes in those parameters in the same subjects during the first 10-week period on diet, there was no significant difference (Table 1), i.e. the significant improvement in glucose tolerance and the lack of significant change in the insulin secretion after the first 10-week period were still maintained after the second 10-week period with no additional improvement or deterioration in glucose tolerance or significant change in insulin secretion having occurred. However, the small number of subjects available for study on diet alone for the second 10- 을 week period should be borne in mind in interpreting $\frac{\rightarrow}{0}$ these results. Rudnick \& Taylor (1965) also showed a maintenance of the improvement in glucose $N$ tolerance in their diabetic subjects on dietary therapy during the second 2-month period of their study.

Table 2 indicates that in the six 'high-insulin secreting' subjects, in whom fenfluramine $40 \mathrm{mg}$ twice daily was added to the dietary therapy during the second period of 10 weeks, there was a significant improvement in glucose tolerance $(P=0.01)$, when the results were compared with those from diabetics not adhering to therapy; but no significant difference in glucose tolerance from those of the same subjects 
TABLE 3. Average time in minutes of occurrence of the peak of the insulin curve in diabetics after various forms of therapy and in normal controls compared with that in diabetics on first presentation, i.e. untreated

\begin{tabular}{|c|c|c|c|}
\hline & & $\begin{array}{l}\text { Average time in minutes } \\
\text { of occurrence of the peak } \\
\text { of the insulin curve }\end{array}$ & $\begin{array}{l}\text { Significance of difference } \\
\text { from diabetics on first } \\
\text { presentation }\end{array}$ \\
\hline & $\begin{array}{l}\text { Obese 'high-secretors' on first } \\
\text { clinical presentation }\end{array}$ & $78 \cdot 5 \pm 19 \cdot 5$ & - \\
\hline (b) & $\begin{array}{l}\text { Obese 'high-secretors' after diet } \\
\text { alone }\end{array}$ & $73 \cdot 9 \pm 29 \cdot 0$ & NS* \\
\hline (c) & $\begin{array}{l}\text { Obese 'high-secretors' after diet } \\
\text { plus fenfluramine }\end{array}$ & $70 \cdot 0 \pm 15 \cdot 5$ & NS \\
\hline (d) & $\begin{array}{l}\text { Obese 'low- or normal-secretors' } \\
\text { on first clinical presentation }\end{array}$ & $67 \cdot 5 \pm 29 \cdot 3$ & - \\
\hline (e) & $\begin{array}{l}\text { Obese 'low- or normal-secretors' } \\
\text { after diet alone }\end{array}$ & $74 \cdot 0=36 \cdot 5$ & NS \\
\hline (f) & $\begin{array}{l}\text { Obese 'low- or normal-secretors' } \\
\text { after diet plus fenfluramine }\end{array}$ & $72 \cdot 0 \div 34 \cdot 2$ & NS \\
\hline (g) & Normal controls & $39 \cdot 3: 15 \cdot 4$ & $\begin{array}{l}\text { Significantly different from } \\
\text { (a) } P<0.001 \\
\text { Significantly different from } \\
\text { (d) } 0.01>P>0.001\end{array}$ \\
\hline
\end{tabular}

* NS, not significant.

TABLE 4. Range of insulin secretion during the first 30 and $60 \mathrm{~min}$ of the OGTT in subjects categorized as "high-insulin secreting' and 'low- or normal-insulin secreting' diabetics on first presentation.

\begin{tabular}{lcc}
\hline & $\begin{array}{c}\text { Range of insulin } \\
\text { secretion in the } \\
\text { first } \frac{1}{2} \mathrm{hr}\end{array}$ & $\begin{array}{c}\text { Range of insulin } \\
\text { secretion in the } \\
\text { first } 1 \mathrm{hr}\end{array}$ \\
\hline $\begin{array}{c}\text { 'High-insulin secreting' } \\
\text { diabetics }\end{array}$ & $330-1576$ & $1380-6511$ \\
$\begin{array}{c}\text { Normal- or low-insulin' } \\
\text { secreting' diabetics }\end{array}$ & $0-720$ & $0-1995$ \\
\hline
\end{tabular}

after the first 10 -week period on diet alone; i.e. treatment with diet-plus-fenfluramine during the second 10 -week period was associated with maintenance of the improvement in glucose tolerance achieved during the first 10-week period, without any additional improvement or deterioration in this parameter. Furthermore, the addition of fenfluramine produced a significant decrease in insulin secretion when the results were compared with those from the first three sets of controls, and a marginally significant decrease $(P=0 \cdot 10)$ when compared with the fourth set (Table 2). The addition of fenfluramine did not cause any significant changes in 'low- or normal-secreting' obese diabetics, although weight loss occurred in all subjects.

Turtle \& Burgess (1971) found an improvement in glucose tolerance and a decrease in insulin secretion in a series of diabetics treated with diet plus fenfluramine $40 \mathrm{mg}$ twice daily for 3 months. Their patients were within $10 \%$ of their ideal body weight and were taking diets containing 25-30 calories/kg ideal body weight and $35-40 \%$ carbohydrate daily; their oral glucose-tolerance tests were performed $30 \mathrm{~min}$ after ingestion of $40 \mathrm{mg}$ fenfluramine. In contrast, the patients in this present study who showed improvement in glucose tolerance and a reduced insulin secretion were all more than $20 \%$ overweight and were taking lower calorie and carbohydrate-containing diets $(850-1500$ calories and $70-150 \mathrm{~g}$ carbohydrate/day). Furthermore, these subjects had not ingested fenfluramine for 13-15 hr prior to the oral glucose tolerance test. It is probable, however, that only small quantities of the pharmacologically active drug and its metabolites would still be present in the body fluids at the time of the test, since its half-life is about $11 \mathrm{hr}$ (Beckett \& Brookes, 1967). Thus, the changes detected in the present subjects would appear to be associated mainly with a long-term effect rather than direct drug action.

Hence, treatment of 'high-insulin secreting' diabetics with low-calorie diet alone brings about an improvement in glucose tolerance with no significant effect on the insulin secretion. When fenfluramine is added to the dietary treatment, the improvement in glucose tolerance is maintained, and is associated with a significant decrease in insulin secretion, i.e. less insulin is needed to maintain the same level of glucose tolerance. This is in agreement with the finding of increased glucose assimilation in peripheral tissue in the presence of fenfluramine (Turtle et al., 1971; Whichelow et al., 1971). However, apart from a direct action, the results in this present paper indicate that there is a long-term effect of the drug on the handling of glucose by the body.

Kipnis (1968) suggested that the metabolic abnormality in diabetes mellitus is a delayed insulin secretory response to glucose. Table 3 indicates that neither diet alone nor diet-plus-fenfluramine has any significant effect on this aspect of the diabetic state. 
Table 4 illustrates that the division of obese maturity-onset diabetics on first presentation into 'high-insulin' and 'low- or normal-insulin secreting' on the basis of the overall $2 \frac{1}{2}$-hr insulin secretion during an OGTT is justified in that the $30-\mathrm{min}$ and 60-min secretions are also significantly different between the two categories.

Thus, in 'high-insulin secreting' obese diabetics, as in obese non-diabetics (Dykes, 1973), the administration of fenfluramine with diet after a period on diet alone is highly effective in producing a significant decrease in the quantity of insulin secreted. It remains to be seen if this is an important therapeutic effect in view of the suggested association between high plasma insulin concentrations and the development of atheroma (Stout \& Vallance-Owen, 1969).

\section{Acknowledgments}

Thanks are due to Professor Sir Ronald Tunbridge, Dr John Bingle and Dr Frank Higgins for permission to study the patients under their care; to Dr C. J. Hayter, Department of Nuclear Medicine at the General Infirmary, Leeds, for use of the Phillips Counter; to Dr W. L. Burland, Medical Director of Servier Laboratories for advice and encouragement; to Mrs P. Petch and Mrs M. Collingwood for valuable technical assistance; to Miss Diana Whitehead and Mrs A. Stewart for secretarial help; to Mr R. Cartwright for assistance with preparation of the figures for publication.

This work was supported by grants from the British Diabetic Association and Servier Laboratories to whom thanks are expressed. The results were presented at the Fenfluramine Seminar in Nassau, 22-26 February 1971, and the Symposium on Obesity held at Cambridge in the Postgraduate Medical Centre on 6 May 1972.

\section{References}

BeCketT, A.H. \& Brookes, L.G. (1967) The absorption and urinary excretion in man of fenfluramine and its main metabolite. Journal of Pharmacy and Pharmacology, 19, Suppl., 42S-49S.

Burns, T.W., Bregant, R., van Peenan, H.J. \& Hood, T.E. (1965) Evaluation of the oral glucose tolerance test by a continuous sampling technique. Journal of Laboratory and Clinical Medicine, 65, 927.

Butterfield, W.J.H. \& Holling, H.E. (1959) Peripheral glucose metabolism in fasting control subjects and diabetic patients. Clinical Science, 18, 147.

CRADDOCK, D. (1969) In: Obesity and its Management, p. 80. E. \& S. Livingstone, Edinburgh.

DYKES, J.R.W. (1973) The effect of a low calorie diet with and without fenfluramine and fenfluramine alone on the glucose tolerance and insulin secretion of overweight nondiabetics. Postgraduate Medical Journal, 49, 314.

Foxwell, M.G., FunderburK, W.H. \& WARD, J.W.J. (1969) Studies on the site of action of a new anorectic agent, fenfluramine. Journal of Pharmacology and Experimental Therapeutics, 165, 60.
Hales, C.N. \& RaNDle, P.J. (1963) Immunoassay of insulin with insulin-antibody precipitate. Biochemical Journal, 88, 137.

Hales, C.N., Stein, J. \& Stowers, J.M. (1966) Abnormal control of the metabolism of non-esterified fatty acid in obesity. In: Proceedings of the Congrès Européen sur les maladies nutritionnelles et dysmetaboliques: Rein et Foie, Maladies de la Nutrition, IX, p. 387. Vittel, France.

von Herold, E., Kemper, F. \& OpItz, K. (1965) Einfluss appetithemmender substanzen auf kohlenhydrate und fettsäurestoffwechsel. Arzneimittel Forschung, 15, 657.

Himsworth, H.P. (1949) The syndrome of diabetes mellitus and its causes. Lancet, $\mathbf{i}, 465$.

Karam, T.H., Grodsky, G.M., Pavlatos, F.C. \& Forsham, P.N. (1965) Critical factors in excessive serum insulin response to glucose; obesity in maturity-onset diabetes and growth hormone in acromegaly. Lancet, i, 286.

KIPNIS, D.M. (1968) Insulin secretion in diabetes mellitus. Annals of Internal Medicine, 69, 891.

McKiddie, M.T. \& Buchanan, K.D. (1969) Plasma insulin studies in 200 patients with diabetes mellitus. Quarterly Journal of Medicine, 38, 445.

Morley, G., Dawson, A. \& Marks, V. (1968) Manual and AutoAnalyzer methods for measuring blood glucose using guaiacum and glucose oxidase. Proceedings of the Association of Clinical Biochemists, 5, 42.

Perley, M. \& Kipnis, D.M. (1965) Differential plasma insulin response to oral and infused glucose in normal weight and obese non-diabetic and diabetic subjects. Journal of Laboratory and Clinical Medicine, 66, 1009.

Perley, M. \& KIPNIS, D.M. (1966) Plasma insulin response to glucose and tolbutamide of normal weight and obese diabetic and non-diabetic subjects, Diabetes, 15, 867.

RUdNICK, P.A. \& TAYLOR, K.W. (1965) Effect of prolonged carbohydrate restriction on serum insulin levels in mild diabetes. British Medical Journal, 1, 1225.

SocIETY OF ActUARIES. (1959) In: Build and Blood Pressure Study, Vol. 1. Chicago.

SOKAL, R.R. \& RohlF, F.J. (1969) In: Biometry, p. 391. W. H. Freeman and Co., San Francisco.

Stout, R.W. \& Vallance-Owen, J. (1969) Insulin and atheroma. Lancet, i, 1078.

TURTLE, J.R. \& BURgess, J.A. (1971) Therapeutic value of fenfluramine as a hypoglycaemic agent in diabetes mellitus. In: Fenfluramine Seminar, p. 201. Servier Laboratories Ltd.

Turtle, J.R., Burgess, J.A. \& Bauckham, S. (1971) Forearm perfusion and intravenous infusion of fenfluramine in normal subjects. In: Fenfluramine Seminar, p. 185. Servier Laboratories Ltd.

Whichelow, M.J., Butterfield, W.J.H., Asmal, A.C., Boucher, B.J. \& Karamanos, B. (1971) Peripheral metabolism in obesity; the effect of weight reduction by diet and fenfluramine. In: Fenfluramine Seminar Addendum, p. 69. Servier Laboratories Ltd.

Yalow, R.S., Glick, S.M., Roth, J. \& Berfon, S.A. (1965) Plasma insulin and growth hormone levels in obesity and diabetes. Annals of the New York Academy of Sciences, 131, 357. 